\title{
Analysis Characteristic of Province Travelling Intercity of AKDP Makassar-Parepare Route, South Sulawesi
}

\author{
St.Maryam $\mathrm{H}^{1}$, Herman Parung ${ }^{1}$, Tri Harianto ${ }^{1}$, and Muh.Isran Ramli ${ }^{1}$
}

\begin{abstract}
Intercity Transportation is a kind of transportation that connects one city to other cities that are still located in one provincial administrative region or province intercity, as well as located in the other provinces. province intercity service works in one route network and the road infrastructure as contained in the regulation route reguirement. The type and amount of Goods Mode In this study are Damri Bus, Minibus, BMA, and the types of MPU vehicles conprises of Panther, Kijang, Avanza etc. The purpose of this study is to analyse the travelling Charakteristics of AKDP that comprises of passenger and operator, travelling expense of AKDP, which is covering of passenger expense and operational vehicles cost (BOK) of Makassar-Pare pare route. The survey of data collection for passengers was done at the locations of departure and transit of province intercity transportation that is in Daya regional terminal and unofficial terminals in a number of departure points along Perintis Kemerdekaan Street up to the borders of Makassar, the base of public transportation of province intercity base located in Makassar suburban areas and the stopovers province intercity Barru and Parepare.
\end{abstract}

Keywords—travel characteristics, province intercity, travel cost.

\section{INTRODUCTION}

M akassar city is one of the major cities in Indonesia that continue to undergo rapid development from year to year, the developments are caused by the increasing population in Makassar and Makassar's position as a center of economic development and as educational city in Eastern Indonesia became the factor of population urbanization process which resulted in an increasing of population numbers and of course have an impact on increasing of people and goods transport especially inter regional within the province. Inter regional transportation is a transportation that connects a city with other cities whether in one administration region province, between cities in the provinces (AKDP), or in the other provinces. AKDP services perform in the network routes and organized with discrete service, i.e. the availability of passenger terminal at least type $\mathrm{B}$ at the beginning of the departure, stopover, and terminal destination, as well as road infrastructure undertaken as listed in the route permission that has been set.

In an inter regional movement, factor selection mode is a very important role, a person who will travel from one city to another certainly consider many things, whether he would use his private vehicles or would use public transportation, there are many selection of transportation mode that may be used [6].

In spite of the transportation mode that serves the Makassar-Parepare route, there are different types of transportation modes such as Damri buses, mini-buses, panther, kijang, etc. Each of these transportation modes has its advantages and disadvantages, so the selection of the transportation mode used of course based on the fact that the traveler has a number of specific reasons and considerations to determine the mode that will be used

${ }^{1}$ St.Maryam H, Herman Parung, Tri Harianto, and Muh.Isran Ramli are with Departement of Civil Engineering, Faculty of Engineering, Universitas Hasanuddin, Makasar, Indonesia.

E-mail: ryamhafram@yahoo.co.id; parungherman@yahoo.co.id; triharianto@gmail.com; isranramli@yahoo.com. by looking at all the mode attributes. Parepare town is one of the largest towns in South Sulawesi besides Makassar and also is one of the destination city for AKDP public transportation users. The distance between the Makassar city and Parepare town is approximately \pm $155 \mathrm{~km}$ and passes through several districts such as Maros, Pangkep, Barru till Parepare. AKDP mobility of Makassar-Parepare routes is regarded dense due to the high demand of passengers to use the routes AKDP of Makassar-Parepare routes by diversed reasons and interests.

The problem that arises is lacking the proper functioning of the terminal's role as a place to load and drop the passengers or goods and the arrival place and port setting of public transportation. Because of the level of terminal services that are not optimally utilized as appropriate, make the other side took the opportunity by making "wild terminal" around Regional Terminal of Daya'. Consequently, many of the minibus that was reluctant to get into the terminal to pick up and drop passengers, Finally, AKDP transportation particularly Public Passenger Car (MPU) takes charge outside the terminal which resulted in the AKDP passengers chose to wait at the roadside rather than come into the terminal so that it can be seen along the Jalan Perintis Kemerdekaan to the border of Makassar that a number of recruit passengers is lined up waiting for the transportation.

In the meantime a number of operators or AKDP transportation companies which makes base/pool in Makassar city such as Buses Damri vehicles are located on Jalan Toddopuli and pool of BMA Bus in jalan Gunung Bawa Karaeng, perform their own departures at the base/pool vehicles. They pay retribution to the terminal for their vehicles but does not through the terminal making a lot of AKDP public transportation users in Makassar will no longer have to enter to await at the terminal of departure transportation.

\section{A. Research Objectives}

A series of this research activities aims to analyze the characteristics of the passenger trip as well as the 
selection of inter regional traveling mode in the provinces (AKDP) of Makassar-Parepare route.

\section{B. Transportation System of Public Transportation}

In organizing of the public transport system, there are some related parties, namely the user, entrepreneurs (operator) and the Government (the regulators). Each party has its own interests and policies that can accommodate all party accordance with the functions, rights and obligations that contained in a regulation or legislation. The role of each related party is as follows [10]:

1) Operator (businessman) is the party that concentrates in the operation of public transport systems and carry out everyday decisions with regard to the specific characteristics of the conditions of service, such as scheduling, the determination of the limit of the operations and maintenance fleet.

2) User is the party that actually made the decision during a trip on public transportation system, owing to the magnitude of the cost that they spend on traveling (fare) and other costs (intangibles) are not measured by monetary value, such as waiting time, distance and travel time.

3) Regulators (Government) is the party that controls the interaction between operator and user. The Regulator who reviews the system performance in operational techniques and financial economic as well as to provide specifications for provision and operation of public transportation systems. This regulatory policy is what being a benchmark for the level of services provided by public transport supply.

Transportation is used to facilitate human in performing daily activities. Transportation is an attempt to transfer, move, transport or shift an object from one place to another by using a vehicle that is driven by human or machine, which the places are more useful or can be usefor certain purposes [2].

Intercity In Province Transport (AKDP) Service carried out with the following properties [12]:

1) Have a fixed schedule, such as enlisted in journeyhour, at control-card of operated bus-car.

2) Transportation service conducted with slow or fast services.

3) Served with the big or medium bus-car, for economic or non-economic service.

4) Available of passenger terminal at least type $B$ in the early departure, transit, and target terminal,

5) Available road-path passed by, intercity in province transportation service, such as enlisted in route permit which have been specified.

Terminal represent the important component in system of AKDP transportation, for drop-off and pick-up goods and/or people, and also arrange the arrival and representing one of existing node of transportation network. Legal Fundament of Terminal Management, Pursuant To Decree Of The Ministry Of Communication RI, No. KM.31, 1995. (Road Transportation Terminal).

According to service, terminal can be divided into two types: goods and passanger terminal, respectively. According to function, passenger terminal divided into three types, as follows [12]:
1) Type A, serving: interprovince-intercity transport (AKAP), State Border Passage, AKDP, Urban and Rural Transport,

2) Type B, serving: AKDP, Urban and Rural transport, and

3) Type C, serving: Urban and Rural transport

Transport problems have become more widespread and severe than ever in both industrialised and developing countries alike. Fuel shortages are (temporarily) not a problem but the general increase in road traffic and transport demand has resulted in congestion, delays, accidents and environmental problems well beyond what has been considered acceptable so far. These problems have not been restricted to roads and car traffic alone. Economic growth seems to have generated levels of demand exceeding the capacity of most transport facilities. Long periods of under-investment in some modes and regions have resulted in fragile supply systems which seem to break down whenever something differs slightly from average conditions.

These problems are not likely to disappear in the near future. Sufficient time has passed with poor or no transportation planning to ensure that a major effort in improving most forms of transport, in urban and interurban contexts, is necessary. Given that resources are not unlimited, this effort will benefit from careful and considered decisions oriented towards maximising the advantages of new transport provision while minimising their money costs and undesirable side-effects [3].

\section{Mode Choice Model}

The choice of transport mode is probably one of the most important classic models in transport planning. This is because of the key role played by public transport in policy making. Public transport modes make use of road

space more eficiently than private transport. Also they have more social benefits like if more people begin to use public transport, there will be less congestion on the roads and the accidents will be less. Again in public transport, we can travel with low cost. In addition, the fuel is used more eficiently. Main characteristics of public transport is that they will have some particular schedule, frequency etc. On the other hand, private transport is highly flexible. It provides more comfortable and convenient travel. It has better accessibility also. The issue of mode choice, therefore, is probably the single most important element in transport planning and policy making. It affects the general eficiency with which we can travel in urban areas. It is important then to develop and use models which are sensitive to those travel attributes that influence individual choices of mode[5].

As an island nation, Indonesia in its development is really need an transportation with various modes so that the transportation plans need a modeling technique that can involve several types of modes. Modeling techniques that are currently available are often only involved one mode. If the mode is used more than one times it is usually performed in separate stages (selection mode) or equivalents (distribution/selection mode) without changing the representation network [2].

The model of selection mode is aimed to know the proportion of people who will be using every mode. This process is conducted with the intent to calibrate the model of selection mode in basic year by knowing non 
variables that affect the selection mode or by knowing the attributes and variables that affect the preference of user for the selection the mode. The selection mode is also very influenced by: demand variables that is related to the user socio-economic condition to travel and supply variables that are related to level of service provided by the mode of transportation [7].

\section{Affecting Factors of Mode Choice}

There are several factors that influence the selection modes i.e. as described below [2]:

1) Characteristics of traveling (Travel characteristic factor) variables that are considered to be influenced in the choice of mode, that is the purpose of traveling (go to work, school, social, etc.), traveling time (morning, noon, afternoon, holidays and so on) and the length of the trip (the distance between the origin and destination, the time comparison when using other modes).

2) Characteristics of the trip perpetrators (Traveler characteristic factor) several variables that are considered to affect, namely income, ownership of vehicles, private vehicle condition (old, ugly, new, and so forth), the density of settlement and socioeconomic (e.g., family/household structure, age, gender, type of work, location of work, possession of a driving license (SIM), and so on).

3) The characteristics of the transportation system (Transportation system characteristic factor) variable that affects is traveling time (length of time waiting at arriving place/terminal, running time to arriving place, time during the mode moves, and so forth), traveling costs (fares/rates, fuel costs, parking fees), level of service (service levels is difficult to measure and varies, i.e. include comfort and pleasure variables that makes people easy to change the transportation), level of access/easiness of attainment/destination and the level of reliability of public transportation (in terms of punctuality), the availability of parking spaces and rates.

4) The characteristics of the city and zone (Special characteristic factor) variables that are included affecting is settlement distance to the activity places (CBD) and population density

\section{METHOD}

\section{A. Research Methods}

The implementation of the research is performed to public transportation trip of Makassar-Makassar route, where Makassar as a center of the movement.

Data retrieval methods are placed at the departure location in Regional Terminal of Daya', wild terminal in some points of the departure location along the road of Jalan Perintis Kemerdekaan to the border of Makassar, and at base/pool of public transportation in Makassar.

Based on the survey results, the transportation mode type on the study area of Makassar-Parepare route is differentiated into 4 types of vehicles (Figure 1.) including:

1) Damri Buses Vehicle (BD), with transport capacity is 49 seat

2) Mini Bus Vehicle (MB), with transport capacity is 28 seat

3) BMA car with transport capacity is 9 seat
4) Public transportation car (MPU), Panther, Kijang, Avanza, etc., with transport capacity is 8 seat.

Population is the collection of objects that is examined. Population is not only just the number that exists on the object/subjects are studied but also covers the whole characteristics/properties that is owned by the object/subject [4]. In this study the population is all over the transportation modes users of Makassar-Parepare by calculating the number of passengers per day for each mode where the observations is conducted during a week.

Sample is a subset of the number and characteristics of which are owned by the population. Mathematically, the size of samples from a population is small or smaller than 10,000 can be formulated as follows:

$$
\mathrm{n}=\frac{\mathrm{N}}{1+\mathrm{Nd}^{2}}
$$

data collection method is carried out by three ways i.e., observation, interview and questionnaires that are distributed to passengers on inter regional public transport where the methods is analyzed by the multinomial logit model. The estimation of travel mode choice models is an important component of urban and intercity travel demand analysis and has received substantial attention in the transportation literature (see Ben-Akiva and Lerman, 1985). The most widely used model for urban as well as intercity mode choice is the multinomial logit model (MNL). The MNL model is derived from random utility maximizing behavior at the disaggregate individual level. This is the simplest and most popular practical discrete choice model (Domencich and McFadden 1975).

The multinomial logit model (MNL) choice probabilities are[3]:

$$
P_{i q}=\frac{\exp \left(\beta V_{i q}\right)}{\sum_{A_{j} A(q)} \exp \left(\beta V_{i q}\right)}
$$

\section{RESULT AND DISCUSSION}

\section{A. Characteristics of the Mode Choice}

Based on the analysis results, the characteristics of the selection mode with the number of respondents are 1064 people, obtained percentage of people who choosing Damri Buses is 308 people respondents (29\%), Mini Bus is 276 people respondents $(26 \%)$, BMA Bus is 142 people (13\%) and passenger cars (MPU) and public passenger car is 336 people respondents (32\%), where the highest mode percentage option is MPU vehicle type as the following table 1 . One factors that causing many passenger who choosing MPU transportation compared to other types of vehicles is caused by the number of this vehicle type which operate every day.

Therefore the MPU departure time is any time if compared to the types of Damri bus and the BMA vehicle hat have to wait departure schedule or wait until the vehicle is fully loaded such as mini buses. Meanwhile the lowest mode option is the type of BMA Bus vehicle. The factors that cause these are low passengers who choose this type of vehicle is likely due 
to factors of a very expensive price when compared to other vehicles.

\section{B. Traveling Characteristics}

The characteristics of the AKDP passenger trip of Makassar-Parepare describes the transportation that is used and the reasons for using such type of transportation, travel intentions, distance range forecasts from home to the terminal/pool, distance range forecasts from Makassar to Parepare destination, traveling time forecast from home to the terminal/Pool, traveling time forecasts from Makassar to Parepare destination, costs forecast from home to the terminal/AKDP Pool, costs forecast from Makassar to Parepare destination (including transportation rates, eating and drinking during the trip).

1) Reasons for using transportation type

Based on the survey and analysis results, the highest reason for choosing a vehicle in traveling is due to the traveling time with a MPU transportation type as many as 93 people from 183 respondents $(51 \%)$, in second place by the comfort and safety reason of BMA transportation type is as many as 45 people from 103 respondents (43\%), and Damri bus is in the third position by traveling costs reason for this mini bus transportation type as much as 67 people from 164 respondents $(41 \%)$ furthermore for convenience reasons for Damri buses type transportation is as many as 54 people $(31 \%)$ of 172 respondents $(31 \%)$, then with the availability of transportation reason is as many as 39 people for MPU transportation is as many as 183 respondents (21\%). Last, punctuality reason of departing/arriving for BMA vehicle type is as much as 14 people from 104 respondents (13\%). From Figure 2, seen by that, to the reason of in chosening mode of consumer of MPU-mode very predominating, because MPUmode (AKDP) is true mean run high-speedly by all its driver.

This affect at reason of security, where mode-user tend to to chosen third moda (Damri Bus, Mini Bus, and BMA Bus) than MPU-Bus.

2) Traveling intention

The intention to travel from Makassar to Parepare is mostly by the family purpose of Damri buses transportation type (48\%), mini bus (50\%) and MPU (49\%). While the highest purpose for the BMA transportation type in traveling from Makassar to Parepare is for traveling business/work as much as $(40 \%)$.

For the characteristic of traveling intention is such as those which seen at Figure 3, traveling intention mean predominated by intention to work/business and family traveling, intention for the education traveling is very minim, because consumer mean conduct the school activities at its town. For the purpose of above mean recreation $10 \%$ from consumer which its opportunity intentionally its time for the recreation of outside Makassar City at Makassar-Parepare route.

3) Last education level

Respondents with graduate education level (S1) is the most respondents in order to travel from Makassar to Parepare by using Damri Buses (37\%), Mini Bus (36\%), and the BMA (39\%), respondents with high school (S1) last education level is mostly using MPU transportation-mode as much as $32 \%$. The level of last education (Figure 4), consumer mean which is a lot of using to this four mode, owning last education level (Diploma, S1, and S2 respectively), this is indication that consumer mean conducting business/work, and family traveling respectively, (Figure 3) owning last education level of Diploma, S1, and S2 respectively.

4) The respondent's occupation

Percentage of respondents using Damri public transport buses and mini buses is mostly working as private employees, i.e. (28\%) and (26\%), BMA bus is mostly as a businessmans/self-employments (32\%) and MPU transportation is mostly students (25\%). Base of Occupation Characteristic (Figure 5), consumer which incline to chosen to four moda in conducting traveling is Civil Servants (PNS) and Private Employees (average 20\%), the consumer of with the business/work traveling seen by more incline to chosen the BMA-mode (average 30\%).

For the student more incline to chosen three mode, that is Damri-Bus, Mini-Bus, and MPU-Bus (average 20\%), and only about 5\% from them, chosening BMA-Bus.

\section{5) The respondent's average income}

From the survey and analysis results are known that the highest respondents' income who traveling is under IDR2000.000,-per-month by using mini-bus public transportation (45\%) and MPU (40\%). The income is between IDR 2000.000, to IDR 3,500,000,-per-month respectively: by using Damri buses (35\%), mini bus (33\%) and MPU $(33 \%)$. Respondents with an income between IDR 3,500,000,- to IDR 5000.000,-per-month are mostly using BMA bus as much as $43 \%$.

For the characteristic of income (Figure 6) there are more than $30 \%$ consumer using to four moda, its haved income under IDR 5.000.000,- permonth This matter indication that consumer of moda mean be at the middle economic level downwards. Where income level between IDR 2.000.000,- to IDR 3.000.000, what is the more amount predominating use to this four moda. Consumer with greater than IDR 3.500.00, per month income level, seen by more incline to chosen the Bus BMA (40\%) in conducting its traveling.

\section{CONCLUSION}

1. The characteristic of mode choice for the type of transportation was MPU (32\%), Bus Damri (29\%), Bus (26\%), and Bus BMA (13\%), respectively.

2. Characteristic of Travelling of MakassarParepare route:

a. Factors having an effect on by significantly among other things most dominant:

i. Speed/travel time, for the type of MPU transportation was $51 \%$.

ii. Convenience and Safety for the type of BMA and bus Damri transportation, was $43 \%$, and $37 \%$ respectively. 
iii. Traveling cost for the type of mini bus transportation was $41 \%$.

b. Intention conduct the traveling with the family journey, by the transportation of bus damri (48\%), bus (50\%) and MPU (49\%), respectively. For a while for the purpose of business/working traveling is type of BMA (40\%)

c. Level of Education of Under-Graduate responder a lot of conducting traveling by using Bus Damri (37\%), Bus (36\%), and BMA $(39 \%)$ respectively, and level of education of High School by using of MPU (32\%).

\section{REFERENCES}

[1]. B. M. Akiva, and S. R. Lerman. Discrete Choice Analysis Theory and Application to Travel Demand. The MIT Press. Cambridge, Massachusetts. London, England, 1985

[2]. F. Miro, "Perencanaan Transportasi," Jakarta: Erlangga, 2005.

[3]. J, de D.Ortúzar,and L.G. Willumsen. Modelling Transport (4th Edition). John Wiley \& Sons, Ltd., 2011.

[4]. Sugiyono, "Statistik untuk Penelitian," Bandung: Alfabeta, 2006.

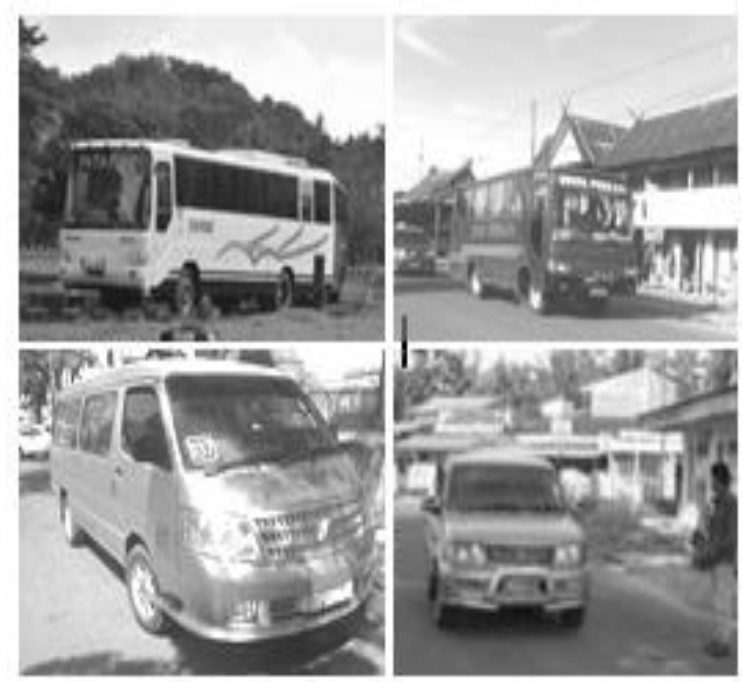

Figure 1. Moda Bus Damri and Mini Bus, BMA and MPU (left to right)

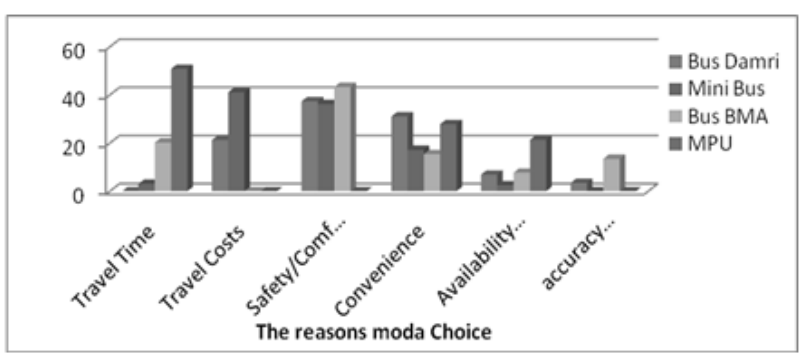

Figure 2. The reason for using this type of moda

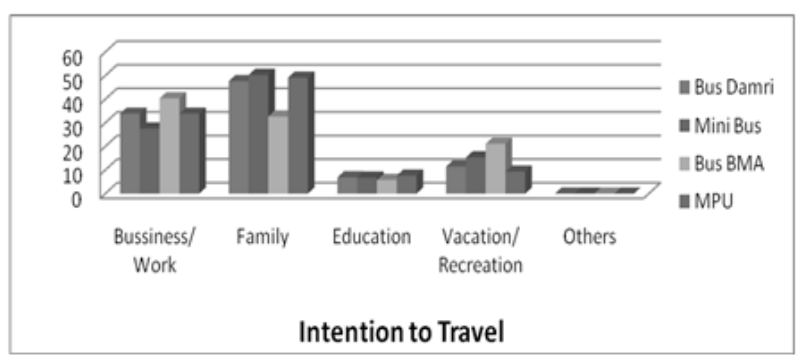

Figure 3. Travelling Intention
[5]. T.V. Mathew, and K. V. Krishna, Introduction to Transportation Engineering. NPTEL, 2006.

[6]. Budi Prasetyo, L. Bambang. "Pemodelan Perpindahan Antar Moda Pada Jaringan Perangkutan Barang (Studi Kasus Pulau Jawa)," Jurnal Forum Studi Transportasi antar Perguruan Tinggi (FSTPT), UGM Yogyakarta, 2000. (3)

[7]. R. Rahman, "Studi Pemilihan Moda Angkutan Umum Antar Kota Menggunakan Metode Stated Preference," Jurnal SMARTek, vol. 7-4, pp. 229-243, Nop. 2009.(4)

[8]. R. Rahmatang, "Analisa Biaya Operasi Kendaraan (BOK) Angkutan Umum Antar Kota dalam Provinsi, Rute Palu-Poso," Jurnal Rekayasa dan Manajemen Transportasi, vol. II, No. 1, 2012. (5)

[9]. S. Sebayang, S. Soehodho, and M. Alvinsyah, "Karakteristik Pelaku Perjalanan Dalam Memilih Moda Angkutan Umum Antara Bus Non AC, Bus AC, dan Taksi/Travel (Studi Kasus Pelabuhan Bakauheni-Bandarlampung)," Jurnal Transportasi Forum Studi Transportasi antar Perguruan Tinggi (FSTPT), Bali, 2001.(6)

[10]. M. P. Siswoyo, "Kebijakan dan Tantangan Pelayanan Angkutan Umum," Jurnal Teknik Sipil dan Perencanaan, No. 2, vol. 10, UNNES, 2008.(7)

[11]. B. Setiowati et. al., "Studi Komparasi Pemilihan Moda Kereta Api Eksekutif dan Pesawat Terbang (Studi Kasus: Asal Semarang Tujuan Jakarta)," Simposium FSTPT 6 UNHAS. No. Jurnal 77. Makassar, 2003.(8)

[12]. Peraturan Menteri Perhubungan No. KM 35, “Tentang Penyelenggaraan Angkutan Orang di Jalan dengan Kendaraan Umum”, Jakarta, 2003.

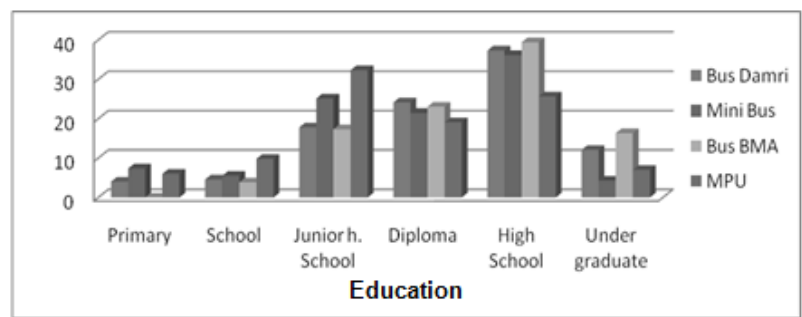

Figure 4. Last Education Level

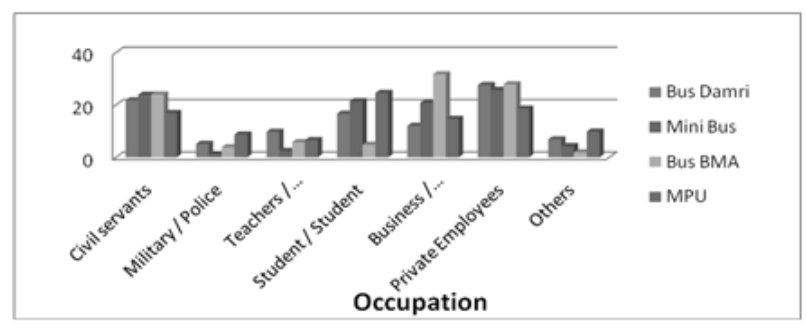

Figure 5. The responden occupation

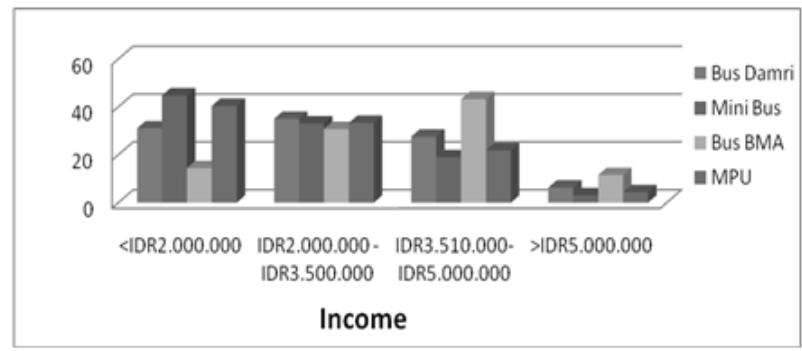

Figure 6. The Responden's average incomae

TABLE 1

Distribution OF Mode ChOICE

\begin{tabular}{ccc}
\hline \hline Type of moda & $\begin{array}{c}\text { Total passenger } \\
\text { (people) }\end{array}$ & $\begin{array}{c}\text { Total passenger } \\
(\%)\end{array}$ \\
\hline Bus Damri & 308 & 29 \\
Mini Bus & 276 & 26 \\
Bus BMA & 142 & 13 \\
MPU & 338 & 32 \\
Total & 1064 & 100 \\
\hline \hline
\end{tabular}

